\title{
Impact of exposed high temperature on hybrid self-compacted concrete.
}

\author{
Nada Mahdi Fawzi ${ }^{1}$, Ammar Saleem Khazaal ${ }^{2}$ \\ ${ }^{1}$ College of Engineering, Baghdad University, Iraq. \\ ${ }^{2}$ College of Engineering, Tikrit University, Iraq.
}

Rec. 20 Jul, 2013 Accept. 2 Sept, 2013

\begin{abstract}
This paper presents an experimental study on the performance of self-compacted concrete (SCC) subjected to high temperature. Two SCC mixtures were tested. For each test, the specimens were heated at a rate of $1{ }^{\circ} \mathrm{C} / \mathrm{min}$ up to different temperatures $\left(150,300,450\right.$ and $\left.600{ }^{\circ} \mathrm{C}\right)$. In order to ensure a uniform temperature throughout the specimen, the temperature was held constant at the target temperature for one hour before cooling. It has noted an important increase in compressive strength of about $11.22 \%$ between 150 and $300{ }^{\circ} \mathrm{C}$ for RSCC job mix specimens at an age of 60 days, and $6.22 \%$ for HSCC job mix specimens for the same age, while at an age of 90 Days RSCC job mix specimens showed an increase of about 3.2\% compared to $3.53 \%$ for HSCC job mix specimens, For HSCC job mix specimens, It has noted that for RSCC job mix specimens, the compressive strength for temperature rate of $450{ }^{\circ} \mathrm{C}$ as in table 15 decreased to $31.01 \%$ and $41.25 \%$ at an ages of 60 and 90 days respectively compared to their relatives in table 14 not exposed to high temperature, and $41.32 \%$ and $48.39 \%$ for temperature rate of $600{ }^{\circ} \mathrm{C}$ at an ages of 60 and 90 days respectively. For HSCC job mix specimens, the compressive strength for temperature rates of $450{ }^{\circ} \mathrm{C}$ decreased to $37.69 \%$ and $40.49 \%$ at an ages of 60 and 90 days respectively compared to their relatives not exposed to high temperature, and $47.55 \%$ and $48.26 \%$ for temperature rate of $600{ }^{\circ} \mathrm{C}$ at an ages of 60 and 90 days respectively, and this is due mainly to alteration of the porous network (Departure of bond water and decomposition of hydrates and to the microcracking).
\end{abstract}

Keywords: Self-compacted concrete, mechanical properties, uniform temperature, heating and cooling.

\section{Introduction:}

Self-compacting concrete (SCC), developed first in Japan in the late 1980s, represents one of the most significant advances in concrete technology in the last two decades. SCC was developed to ensure adequate compaction through self-consolidation and facilitate placement of concrete in structures with congested reinforcement and in restricted areas. SCC can be described as a high performance material which flows under its own weight without requiring vibrators to achieve consolidation by complete filling of the formworks even when access is hindered by narrow gaps between reinforcement bars (Zhu et al., 2001). The high flowability of SCC makes it possible to fill the formwork without vibration (Khayat et al., 2004).
In case of fire, concrete is exposed to high temperature that induces a material degradation: strength decrease, cracking, and in certain conditions spalling can occur. Up to now, the effect of elevated temperature has been studied essentially on vibrated and on high performance concretes. The few studies on SCC subjected to high temperature show both a decrease in strength and an increase in the risk of spalling (Zhu et al., 2001). or a behavior similar to that of vibrated concrete (Okamura and Su et al., 1995). The aim of this study is to analyze the mechanical behavior of SCC subjected to high temperature. Two mixes were investigated: one is Reference RSCC (without adding fibers) and the other is hybrid HSCC (with adding two types of fibers).

$\begin{array}{ll}* \text { Corresponding author: } & 19 \\ \text { Dr. Nada M Fawzi } & \\ \square \text { naljalawi@yahoo.com } & \end{array}$




\section{Materials: \\ Cement:}

Ordinary Portland cement type I was used in all mixes throughout this investigation. It was stored in air-tight plastic containers to avoid exposure to atmospheric conditions like humidity. The chemical and physical properties of cement used in study are presented in Table (1). Test results indicate that the adopted cement conformed to the Iraqi specification

\begin{tabular}{|c|c|c|c|}
\hline Physical Properties & Specification & $\begin{array}{c}\text { Test } \\
\text { Results }\end{array}$ & Limit of IQS 5/1984 \\
\hline $\begin{array}{l}\text { Specific surface area (Blaine } \\
\text { method), }\left(\mathrm{m}^{2} / \mathrm{kg}\right)\end{array}$ & \multirow{4}{*}{ R.G.D 198/1990 } & 460 & $230 \mathrm{~m}^{2} / \mathrm{kg}$ lower limit \\
\hline $\begin{array}{l}\text { Setting time (vacate apparatus) } \\
\text { Initial setting, hrs:min } \\
\text { Final setting, hrs:min }\end{array}$ & & $\begin{array}{l}1: 30 \\
3: 40\end{array}$ & $\begin{array}{l}\text { Not less than } 45 \mathrm{~min} \\
\text { Not more than } 10 \mathrm{hrs}\end{array}$ \\
\hline $\begin{array}{c}\text { Compressive strength } \mathrm{MPa} \\
\text { For 3-day } \\
\text { For 7-day }\end{array}$ & & $\begin{array}{l}21.5 \\
31.3\end{array}$ & $\begin{array}{l}15 \mathrm{MPa} \text { lower limit } \\
23 \mathrm{MPa} \text { lower limit }\end{array}$ \\
\hline Expansion by Autoclave method & & 0.36 & $0.8 \%$ upper limit \\
\hline Oxides composition & Specification & Content $\%$ & Limits of IQS 5/1984. \\
\hline $\mathrm{CaO}$ & R.G.D 472/1993 & 62.25 & - \\
\hline $\mathrm{SiO}_{2}$ & & 22.87 & - \\
\hline $\mathrm{Al}_{2} \mathrm{O}_{3}$ & & 4.47 & - \\
\hline $\mathrm{Fe}_{2} \mathrm{O}_{3}$ & & 3.07 & \\
\hline $\mathrm{MgO}$ & & 2.38 & $5 \%$ Max. \\
\hline $\mathrm{SO}_{3}$ & & 2.47 & $2.8 \%$ Max. \\
\hline L.O.I & & 1.22 & $4 \%$ Max. \\
\hline Insoluble material & & 1.27 & $1.5 \%$ Max. \\
\hline Lime Saturation Factor, (L.S.F) & & 0.85 & $(0.66-1.02)$ \\
\hline \multicolumn{4}{|l|}{ Main Compounds } \\
\hline $\mathrm{C}_{3} \mathrm{~S}$ & 38.14 & & \\
\hline $\mathrm{C}_{2} \mathrm{~S}$ & 37 & & \\
\hline $\mathrm{C}_{3} \mathrm{~A}$ & 6.65 & & \\
\hline $\mathrm{C}_{4} \mathrm{AF}$ & 9.34 & & \\
\hline
\end{tabular}

Table 1: Physical and Chemical Properties of used Cement.

\section{Aggregates:}

\section{Fine Aggregate:}

Normal weight natural sand from Al-Tuz region East of Tikrit Area was used as fine aggregate. The grading of the fine aggregate conformed to the requirements of Iraqi specification 45/1984 as shown in Table (2). The Physical and chemical tests of sand used throughout this work are shown in Table (3). Results also indicate that the fine aggregate grading and sulfate content are within the requirement of the Iraqi specification 45/1984.

\begin{tabular}{|c|c|c|c|}
\hline Sieve size $(\mathrm{mm})$ & Specification & Cumulative passing $\%$ & Limit of Iraqi specification $45 / 1984$ Zone 3 \\
\hline 10 & \multirow{7}{*}{$\begin{array}{c}\text { IQS } \\
30 / 1984\end{array}$} & 100 & 100 \\
\hline 4.75 & & 100 & $90-100$ \\
\hline 2.36 & & 92 & $85-100$ \\
\hline 1.18 & & 80 & $75-100$ \\
\hline 0.6 & & 61 & $60-79$ \\
\hline 0.3 & & 20 & $12-40$ \\
\hline 0.15 & & 4 & $0-10$ \\
\hline
\end{tabular}

Table (2): Grading of fine aggregate. 


\begin{tabular}{|c|c|c|c|}
\hline Properties & Specification & $\begin{array}{c}\text { Test } \\
\text { Results }\end{array}$ & $\begin{array}{c}\text { Limits of Iraqi } \\
\text { specification 45/1984. }\end{array}$ \\
\hline Specific gravity & (IQS) 31-84 & 2.54 & \\
\hline Absorption \% & (IQS) 31-84 & 2.1 & \\
\hline Sulfate content (as $\mathrm{SO}_{3}$ ), \% & $\begin{array}{c}\text { R.G.D } \\
\text { 500/1994 }\end{array}$ & 0.25 & $0.5 \%$ (max. value) \\
\hline $\begin{array}{c}\text { Material finer than } 0.075 \mathrm{~mm} \\
\text { sieve \%. }\end{array}$ & (IQS) 30-84 & 1.7 & $5 \%$ (max. value) \\
\hline
\end{tabular}

Table (3): Chemical and physical properties of fine aggregate.

\section{Coarse Aggregate:}

Local naturally River Gravel was used of nominal max. size $14 \mathrm{~mm}$ as coarse aggregate. It was received in Big Trucks from North of Tikrit Area. The aggregate for each batch was washed by water in order to remove the dust associated with coarse aggregate. High proportion of dust leads to segregation and causes crazing of exposed concrete (Taylor, 1990). The grading of Coarse aggregate conformed to the requirements of Iraqi Specifications 45/1984 as shown in Table (4).
The coarse aggregate was dripped off and spread inside the laboratory in order to bring the aggregate particles to saturated surface dry (SSD) condition. Due to the rapid water absorption of this aggregate, fast washing would be enough for saturation, whereas the surface drying has been done by spreading the aggregate in the laboratory air for a suitable time. Several physical and chemical properties were determined for coarse aggregate. Table (5) lists these properties and their corresponding proper specifications.

\begin{tabular}{|c|c|c|c|}
\hline Sieve size (mm) & \multirow{2}{*}{ Specification } & Cumulative passing \% & Limit of IQS 45/1984 \\
\hline 20 & \multirow{4}{*}{ IQS 30/1984. } & 100 & 100 \\
\cline { 3 - 4 } & & 96 & $90-100$ \\
\cline { 3 - 4 } & & 73 & $50-85$ \\
\hline 14 & & 3 & $0-10$ \\
\hline 5 & - & - \\
\hline 2.36 & & - & \\
\hline
\end{tabular}

Table (4): Selected grading of coarse aggregate.

\begin{tabular}{|c|c|c|c|}
\hline Properties & Specification & Test Results & $\begin{array}{c}\text { Limits of Iraqi } \\
\text { Specification 45/1984 }\end{array}$ \\
\hline Specific gravity & (IQS) 31-84 & 2.6 & \\
\hline Absorption \% & (IQS) 31-84 & 1.5 & $0.1 \%$ \\
\hline Sulfate content (as SO $\mathbf{3}$ ), \% & R.G.D 500/1994 & 0.06 & $3 \%$ \\
\hline Material finer than $\mathbf{0 . 0 7 5} \mathbf{~ m m ~ s i e v e , ~ \% ~}$ & (IQS) 30-84 & 1.21 & \\
\hline
\end{tabular}

Table (5): Chemical and physical properties of Coarse Aggregate.

\section{Admixtures: \\ High Range Water Reducing Admixture (HRWRA):}

A super plasticizer type (Structro 335) high performance concrete super plasticizer based on polycarboxylic technology was used throughout this investigation as a (HRWRA). Structuro 335 as its technical description presented in Table (6) is differentiated from conventional superplasticisers in that it is based on a unique carboxylic ether polymer with long lateral chains. This greatly improves cement dispersion. At the start of the mixing process an electrostatic dispersion occurs but the presence of the lateral chains, linked to the polymer backbone, generate a steric hindrance which stabilizes the cement particle's capacity to separate and disperse. This mechanism considerably reduces the water demand in flowable concrete. Structuro 335 combines the properties of water reduction and workability retention. It allows the production of high performance concrete and/or concrete with high workability. Structuro 335 is a 
particularly strong superplasticiser allowing production of consistent concrete properties around the required dosage.

\begin{tabular}{|c|c|}
\hline Description & Concrete Superplasticizer \\
\hline Appearance & $\begin{array}{c}\text { Light yellow to reddish } \\
\text { colored liquid }\end{array}$ \\
\hline $\mathrm{pH}$ & 6.5 \\
\hline Volumetric Mass & $1.10 \mathrm{~kg} / \mathrm{ltr}$ @ $20^{\circ} \mathrm{C}$ \\
\hline Chloride Content & $<0.1 \%$ \\
\hline Alkali Content & $\begin{array}{c}\text { Typically less than } 1.5 \mathrm{gm} \\
\text { Na2O equivalent } / \text { liter of } \\
\text { admixture }\end{array}$ \\
\hline
\end{tabular}

Table (6): Technical description of high range water reducing admixture (Typical properties).

High Performance Cohesion Agent (VMA):

A High performance cohesion agent called Structro 480 as its technical description presented in Table (7) is specially designed to ensure a good consistency and stability in selfcompacting concrete was used as viscosity modifying agent which particularly adapted to the production of self-compacting concrete, Provides hydraulic binder-based material excellent stability, opposes sweating segregation and sedimentation in treated concrete results in concrete with a high level of fluidity that can be poured and placed by gravity avoiding vibration.

\begin{tabular}{|c|c|}
\hline Description & Concrete Stabilizer \\
\hline Appearance & Opaque Liquid \\
\hline Specific Gravity & $1.01 @ 20^{\circ} \mathrm{C}$ \\
\hline Chloride Content & $<0.1 \%$ \\
\hline
\end{tabular}

Table (7): Technical description of High Performance Cohesion Agent (VMA) admixture (Typical properties).

\section{Silica Fume:}

Micro-Silica was used in this investigation is Elkem Micro SilicaMEYCO® MS610, a concrete additive of a new generation in powder form. The Physical Description, Chemical analysis, and test result of activity index of micro-silica are given in Table (8).

\begin{tabular}{|c|c|}
\hline Description & Concrete Superplasticizer \\
\hline Appearance & Light Grey Powder \\
\hline $\begin{array}{c}\text { Chemical } \\
\text { Base }\end{array}$ & Powder Containing Silica Fume \\
\hline Density & $0.65 \mathrm{Kg} /$ Liter \\
\hline
\end{tabular}

Table (8): Technical description of Silica Fume (Typical properties)

\section{Mixing Water:}

Ordinary tap water was used for mixing and curing for all concrete mixes of this investigation.

\section{Fibers:}

\section{Polypropylene Fibers:}

High performance short12 $\mathrm{mm}$ polypropylene fibers were used in this investigation. Table (9) indicates the physical properties of polypropylene used throughout this work.

\begin{tabular}{|c|c|}
\hline Form & $\begin{array}{c}\text { 100\% Virgin Polypropylene } \\
\text { Fiber }\end{array}$ \\
\hline Specific gravity & $0.91 \mathrm{~g} / \mathrm{cm} 3$ \\
\hline Alkali content & Nil \\
\hline Sulfate content & Nil \\
\hline $\begin{array}{c}\text { Chloride } \\
\text { content }\end{array}$ & Nil \\
\hline $\begin{array}{c}\text { Air entrainment } \\
\text { not be significantly increased }\end{array}$ \\
\hline Young modulus & $(3500-4800) \mathrm{MPa}$ \\
\hline Tensile strength & $350 \mathrm{MPa}$ \\
\hline Melting point & $160-170^{\circ} \mathrm{C}$ \\
\hline Fiber length & $12 \mathrm{~mm}$ \\
\hline Ignition Point & $590^{\circ} \mathrm{C}$ \\
\hline $\begin{array}{c}\text { Cement } \\
\text { Compatibility }\end{array}$ & Excellent \\
\hline
\end{tabular}

Table (9): Physical properties of polypropylene fibers (PPF).

\section{Steel Fibers:}

Dramix Trade Mark ZP-305 High performance high strength steel fibers for structural reinforcement were used in this study. Table (10) indicates the properties of Dramix ZP-305 steel fibers that were used in this work. 


\begin{tabular}{|c|c|}
\hline Form & $\begin{array}{c}\text { 100\% Virgin } \\
\text { Polypropylene Fiber }\end{array}$ \\
\hline Young modulus & $210,000 \mathrm{~N} / \mathrm{mm}^{2}$. \\
\hline Tensile strength & $1345 \mathrm{~N} / \mathrm{mm}^{2}$ \\
\hline Diameter & $0.55 \mathrm{~mm}$ \\
\hline Length & $30 \mathrm{~mm}$ \\
\hline
\end{tabular}

Table (10): Physical properties of ZP-305 Dramix Steel Fibers used in study.

\section{Mixture proportions:}

The two concrete mixes investigated in research were developed in College of Engineering/ Tikrit University. Tables (11) and (12) are present their mixture proportions. The admixture content was determined so as to obtain a slump flow larger than $650 \mathrm{~mm}$ for SCC. Each concrete mixture was cast in cylindrical molds of $150 \mathrm{~mm}$ in diameter and $300 \mathrm{~mm}$ in height, $150 \times 150 \times 150 \mathrm{~mm}$ cube molds, and prismatic molds with dimensions $100 \times 100 \times 500 \mathrm{~mm}$. After curing for 60 and 90 days ages in metal containers, the selfcompacted concrete specimens were subjected to the different heating cycles.

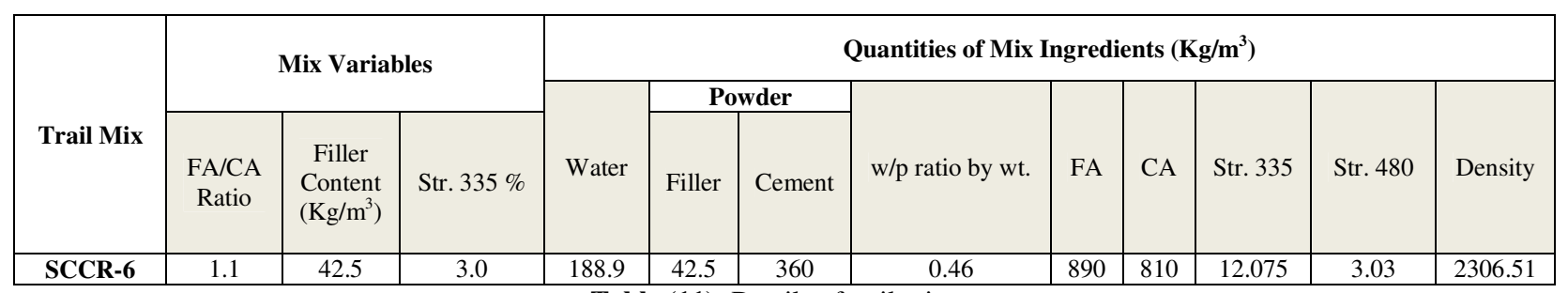

Table (11): Details of trail mixes.

\begin{tabular}{|c|c|c|c|c|c|c|c|c|}
\hline Rank & $\begin{array}{c}\text { Type of } \\
\text { Fiber }\end{array}$ & $\begin{array}{c}\text { Density } \\
(\mathrm{Kg} / \mathrm{m} 3) \text { Df }\end{array}$ & $\begin{array}{c}\text { Volume } \\
\text { Fraction of } \\
\text { Fiber }(\%) \text { Vf } \\
\end{array}$ & $\begin{array}{c}\text { Volume of Job } \\
\text { Mix (m3) }\end{array}$ & $\begin{array}{c}\text { Volume of } \\
\text { Matrix } \\
(\mathrm{m} 3) \mathrm{Vm}\end{array}$ & $\begin{array}{c}\text { Density of } \\
\text { Matrix } \\
(\mathrm{Kg} / \mathrm{m3}) \mathrm{Dm} \\
\end{array}$ & $\begin{array}{c}\text { Fraction Weight of } \\
\text { Fiber to be used in } \\
\text { Mix (Kg) }\end{array}$ & $\begin{array}{c}\text { Fiber } \\
\text { Content } \\
(\mathrm{Kg} / \mathrm{m3})\end{array}$ \\
\hline 1 & Steel & 7860 & 0.5 & 1 & 0.995 & 2264.43 & 1.714 & 38.820 \\
\hline 2 & PPF & 900 & 0.4 & 1 & 0.996 & 2264.43 & 0.159 & 3.609 \\
\hline
\end{tabular}

Tests:

Temperature Test:

The specimens were subjected to four different temperature cycles up to 150,300 , 450 and $600{ }^{\circ} \mathrm{C}$. The first part of each cycle consisted of a heating at $1{ }^{\circ} \mathrm{C} / \mathrm{min}$ up to the target temperature. After that, the temperature was held constant for (1h) in order to ensure uniform temperature throughout the specimens. The last part of the cycles consisted of a cooling down to ambient temperature. The rate of heating refers to the recommendations of the RILEM Technical Committee TC-129 (RILEM Technical Committees 129-MHT). Fig. (1) Presents the theoretical evolutions of temperature as a function of time for the four temperature cycles. The real evolution of thermal shock.

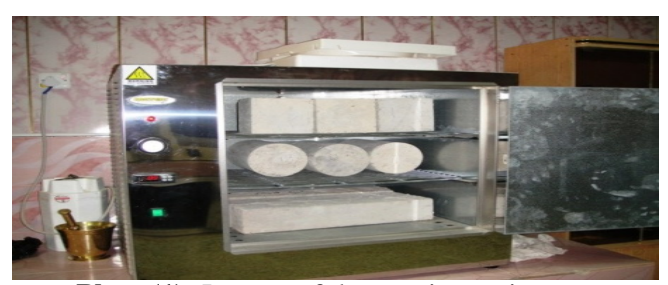

Plate (1): Layout of the specimens in oven. temperature obtained with a heating up to $300{ }^{\circ} \mathrm{C}$ is also indicated. It has observed that the real temperature is very close to the theoretical evolution during heating, whereas the cooling is slower which reduces the risk of thermal shock.

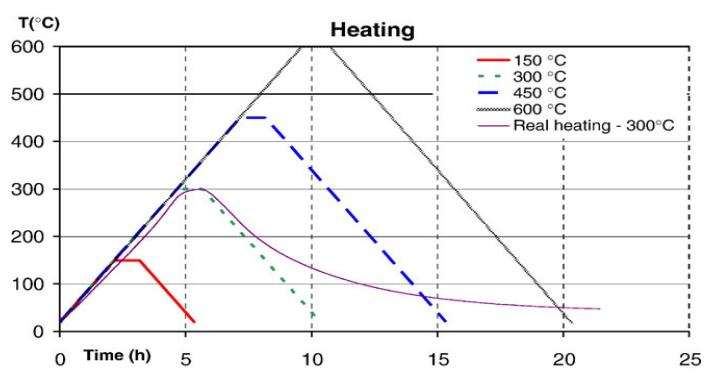

Fig. (1): Heating and Cooling Curves.

\section{Specimens in the oven:}

For each mix and each temperature cycle, nine specimens were stored in the oven. Each batch was composed of three cylindrical specimens $\varnothing 150 \times$ $300 \mathrm{~mm}$, three cube specimens $150 \times 150 \times 150$ $\mathrm{mm}$, and three prismatic specimens $100 \times 100 \times$ $500 \mathrm{~mm}$. All the specimens were stored in the oven in the same condition in order to have a uniform 
temperature. Plate (1) shows the layout of the oven with the specimens.

\section{Mechanical tests:}

Compressive strength:

The compressive strength test was determined according to B.S. 1881: part 116: 1989. This test was conducted on $150 \times 150 \times 150 \mathrm{~mm}$ cubes as shown in Plate (2)using an electrical testing machine with a capacity of $2000 \mathrm{kN}$ at loading rate of $15 \mathrm{~N} / \mathrm{mm} 2$ per minute. The average of three cubes was adopted for each

$$
f_{c}=\frac{P}{A}
$$

Where:

$$
\begin{aligned}
& f c: \text { Compressive strength }\left(\mathrm{N} / \mathrm{mm}^{2}\right) \\
& P: \text { Maximum load applied }(\mathrm{N}) .
\end{aligned}
$$

$A$ : Cross sectional area of the specimens $\left(\mathrm{mm}^{2}\right)$.

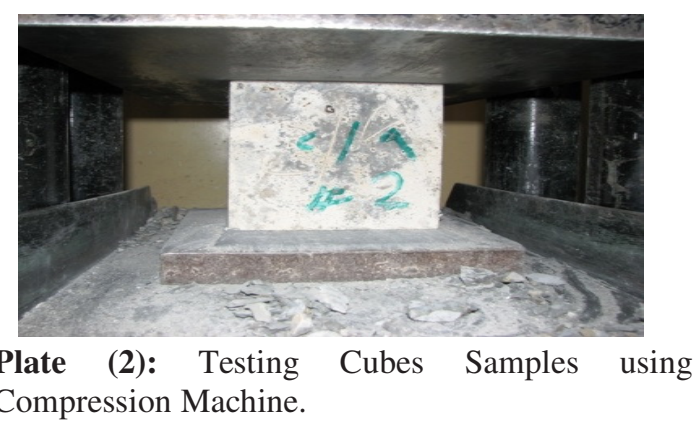

\section{Flexural toughness:}

Flexural toughness test was carried out on $(100 \times 100 \times 500) \mathrm{mm}$ simply supported prisms with a clear span of $400 \mathrm{~mm}$ under the third points loading according to ASTM C1018-97. This test was conducted at ages of 60 and 90 days for both samples of RSCC \& HSCC. The specimens were tested using a Universal Machine in Laboratory of College of Engineering of Tikrit University as shown in Plate (3), and in order to facilitate deflection reading despite the fact that the test was performed upside down without harming the dial gauge The load was applied by using hydraulic machine with capacity of $2000 \mathrm{kN}$. The midspan deflection reading was measured using a dial gauge sensitive to $0.01 \mathrm{~mm}$ then the load deflection has been drawn according to ASTM C1018-97 as shown in Fig. 2.

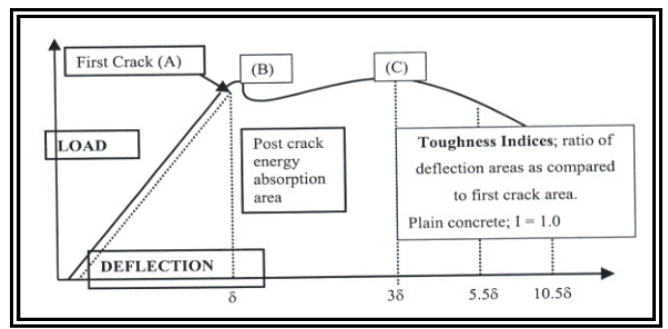

Fig. 2: ASTM C1018, Load-Deflection curve.

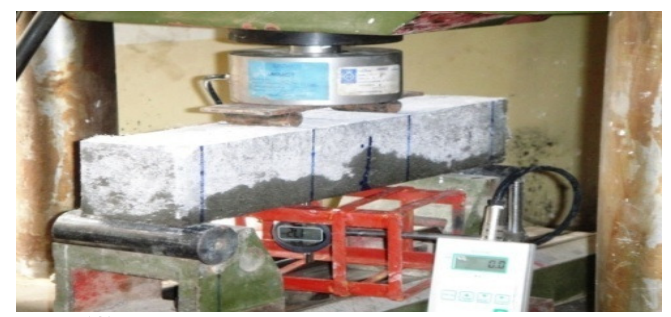

Plate (3): Testing Prisms Samples using Universal machine with capacity of $2000 \mathrm{kN}$.

\section{Results and discussion:}

The mechanical properties compressive strength and flexural strength of the tested concretes before heating are presented in Table (13). It has been observed in Table(13) that the dispersions obtained for the compressive strength of both job mixes RSCC and HSCC, and values of HSCC job mix are slightly higher than those of RSCC job mix and this is due to homogeneity and reproducibility of $\mathrm{SCCH}$ job mix compared to SCCR one.

\begin{tabular}{|c|c|c|c|}
\hline $\begin{array}{c}\text { Age } \\
\text { (Days) }\end{array}$ & $\begin{array}{c}\text { Compressive Strength of } \\
\text { Reference Job Mix SCCR-6 } \\
\left(\mathbf{N} / \mathbf{m m}^{\mathbf{2}}\right)\end{array}$ & $\begin{array}{c}\text { Compressive Strength of Hybrid } \\
\text { Job Mix SCCH-6 } \\
\left(\mathbf{N} / \mathbf{m m}^{\mathbf{2}}\right)\end{array}$ & $\begin{array}{c}\text { \% of Increase in } \\
\text { Compressive Strength }\end{array}$ \\
\hline 7 & 22 & 30 & 27 \\
\hline 14 & 28.59 & 38 & 24 \\
\hline 28 & 37.78 & 49 & 23 \\
\hline 60 & 43.85 & 51 & 14 \\
\hline 90 & 51.64 & 53 & 3 \\
\hline
\end{tabular}

Table (13): Compressive Strength Results of SCC Job Mixes 
During the test, spalling has been observed for both job mixes during the heating up to $450{ }^{\circ} \mathrm{C}$ and $600{ }^{\circ} \mathrm{C}$, spalling occurred around $315^{\circ} \mathrm{C}$ and this observation agrees with (Kanema, 2007). The two job mixes RSCC \& HSCC specimens which spalled possessed an initial compressive strength equal to 22 and $30 \mathrm{~N} / \mathrm{mm}^{2}$ respectively. The variation of residual compressive strength versus temperature is well illustrated in Table (13), Figs. 3 \& 4. It has noted an important increase in compressive strength of about $11.22 \%$ between 150 and $300{ }^{\circ} \mathrm{C}$ for RSCC job mix specimens at an age of 60 days, and $6.22 \%$ for HSCC job mix specimens for the same age, while at an age of 90 days RSCC job mix specimens showed an increase of about $3.2 \%$ compared to $3.53 \%$ for HSCC job mix specimens. Several hypotheses have been proposed in the literature to explain this increase, it attributes to re-hydration of the paste due to migration of water in the pores according to (Eurocode 4, 2005). In another study it assumes that the Silanol groups lose a part of their bonds with water which induces the creation of shorter and stronger Siloxane elements (Si-O-Si) with probably larger surface energies that contribute to the increase in strength according to (Khoury, 1992).
Beyond the $300{ }^{\circ} \mathrm{C}$, the mechanical and physical properties of the tested RSCC and HSCC job mixes specimens decreased quickly. The specimens subjected to a heating up to $600{ }^{\circ} \mathrm{C}$ showed very weak mechanical properties was associated to that of physical properties (Appearance of Cracking). It has noted that for RSCC job mix specimens, the compressive strength for temperature rate of $450{ }^{\circ} \mathrm{C}$ as in Table (14) decreased to $31.01 \%$ and $41.25 \%$ at an ages of 60 and 90 Days respectively compared to their relatives in Table (13) not exposed to high temperature, and $41.32 \%$ and $48.39 \%$ for temperature rate of $600{ }^{\circ} \mathrm{C}$ at an ages of 60 and 90 Days respectively.

It has noted that for HSCC job mix specimens, the compressive strength for temperature rates of $450{ }^{\circ} \mathrm{C}$ as in Table (14) decreased to $37.69 \%$ and $40.49 \%$ at an ages of 60 and 90 days respectively compared to their relatives in Table (13) not exposed to high temperature, and $47.55 \%$ and $48.26 \%$ for temperature rate of $600{ }^{\circ} \mathrm{C}$ at an ages of 60 and 90 days respectively, and this is due mainly to alteration of the porous network (Departure of bond water and decomposition of hydrates and to the microcracking)

\begin{tabular}{|c|c|c|c|c|}
\hline $\begin{array}{c}\text { Age } \\
(\text { Days) }\end{array}$ & $\begin{array}{c}\text { Exposure } \\
\text { Temperature }^{\circ} \mathbf{C}\end{array}$ & $\begin{array}{c}\text { Compressive Strength of } \\
\text { Reference Job Mix RSCC } \\
\left(\mathbf{N} / \mathbf{m m}^{2}\right)\end{array}$ & $\begin{array}{c}\text { Compressive Strength of } \\
\text { Hybrid Job Mix HSCC } \\
\left(\mathbf{N} / \mathbf{m m}^{2}\right)\end{array}$ & $\begin{array}{c}\text { \% of Difference in } \\
\text { Residual Compressive }\end{array}$ \\
\hline \multirow{4}{*}{60} & 150 & 40.56 & 46.00 & 11.8 \\
\cline { 2 - 5 } & 300 & 45.11 & 48.86 & 7.67 \\
\cline { 2 - 5 } & 450 & 30.25 & 31.78 & 4.81 \\
\hline \multirow{3}{*}{90} & 600 & 25.73 & 26.75 & 3.81 \\
\cline { 2 - 5 } & 150 & 46.63 & 48.73 & 4.3 \\
\cline { 2 - 5 } & 300 & 48.12 & 50.45 & 4.61 \\
\cline { 2 - 5 } & 450 & 30.34 & 31.54 & 3.61 \\
\hline
\end{tabular}

Table (14): Residual Compressive Strength Results of SCC Job Mixes after Exposure to High Temperature Rates.

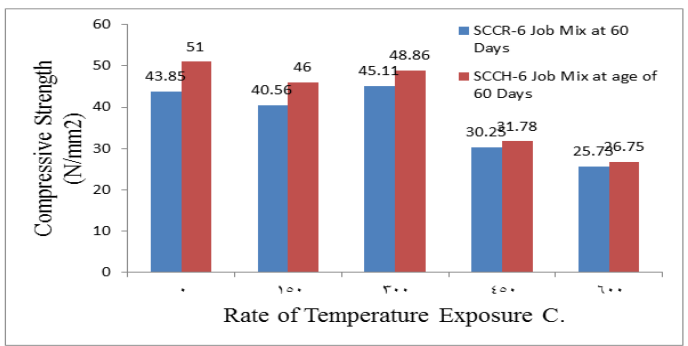

Fig. 3: The variation of residual compressive strength versus temperature of SCCR-6 \& SCCH-6 Job Mixes at age of 60 Days.

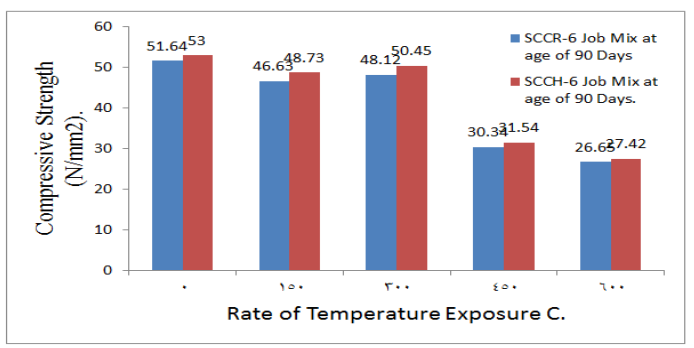

Fig. 4: The variation of residual compressive strength versus temperature of SCCR-6 \& SCCH-6 job mixes at age of 90 days. 


\section{Flexural Toughness:}

Flexural toughness is defined as the energy absorbed by the material when subjected to flexural loading. The toughness for fiber concrete represents the relation improvement in the energy absorption capacity due to the inclusion of fibers relative to the unreinforced matrix and compares the relative energy absorption of different fiber mixes. It is evaluated as the area under the loaddeflection curve, divided by the area under the load-deflection curve up to the first crack strength (Xuet al., 2001). Curves that will be displayed represent the values of load - deflection. Evidences showed that specimens containing no fibers could not sustain any load and failed suddenly when the first crack was developed and hence the toughness index for these specimens at all ages of curing is equal to1.

However, fiber reinforced SCC has the ability of energy absorption to the fibers after first crack appears when it tends to hold the concrete prism together, without causing it to break into two parts. In general, the toughness index for the fiber reinforced SCC varied greatly depending on the fiber type and the distribution of the fibers.

As the deformation of the concrete prism increased, the load capacity of the fibers was decreased. According to Figs. 5 and 6, it has noted that the flexural strength increased with age, and when the sample is subjected to increase in temperature exposure the behavior goes to be varied, so it is upon exposure to $300{ }^{\circ} \mathrm{C}$ there is a considerable increase in ultimate load and then decreased upon temperature exposures of 450 \& $600{ }^{\circ} \mathrm{C}$, and this agrees with data had obtained earlier of both compressive \& Tensile Splitting Strengths.

In Fig. 7 it has noted that the behavior is similar to that of age of 60 days but with small rates of deflection and this is due to continuous hydration which results robust microstructure can sustain loads.

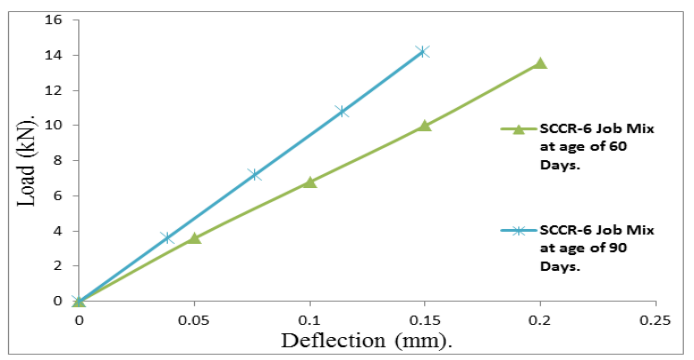

Fig. 5: Load-Deflection Curves of SCCR-6 Job Mix at ages of 7,14,28,60, and 90 Days.

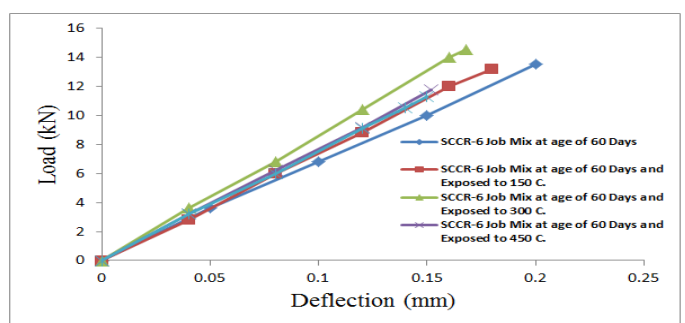

Fig. 6: Load-Deflection Curves of SCCR-6 Job Mix at age of 60 Days and Exposed to temperature rates of $150,300,450$, and $600^{\circ} \mathrm{C}$.

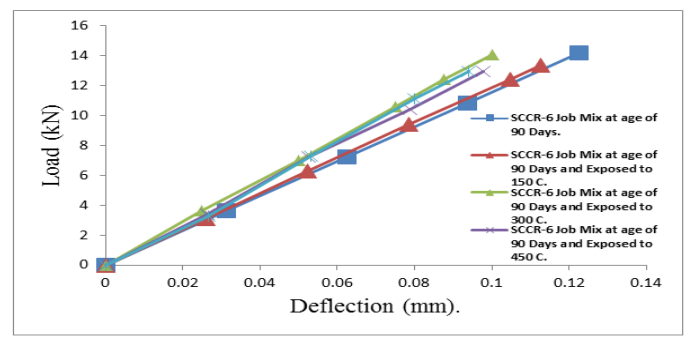

Fig. 7: Load-Deflection Curves of SCCR-6 Job Mix at age of 90 Days and Exposed to temperature rates of $150,300,450$, and $600^{\circ} \mathrm{C}$.

Fig. 8 shows Load-Deflection Curves of HSCC Sample at 60 \& 90 days ages were planned to study which indicate that the flexural strength of sample increased with increase in age.

In Fig. 9 shows load-deflection curves at an age of 60 days and exposed to temperature raise and as shown the curves are interfered but the one was exposed to $600{ }^{\circ} \mathrm{C}$ has the lesser value of ultimate load and an improvement in sustaining flexural load was upon $300{ }^{\circ} \mathrm{C}$ at which a partial improvement in Mechanical properties has noted as in earlier.

Load-Deflection curves at an age of 90 days are showing in Fig. 10 and by compare results with ones in Fig. 9 the difference is well illustrated under the same temperature conditions.

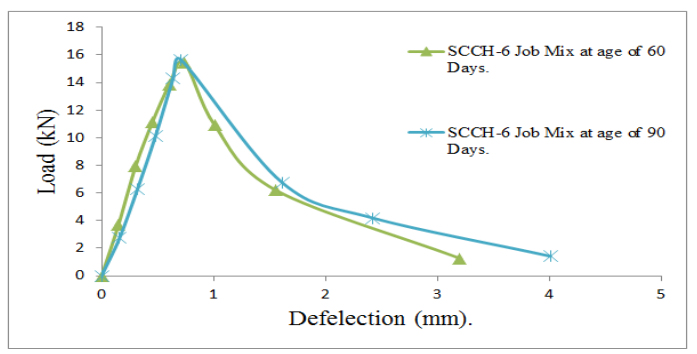

Fig. 8: Load-Deflection Curves of SCCH-6 Job Mix at ages of 60 and 90 Days. 


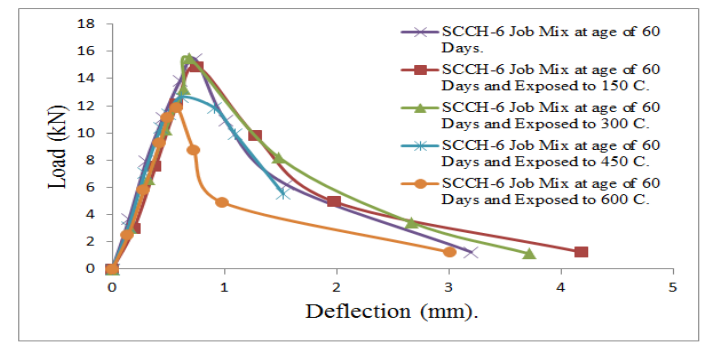

Fig. 9: Load-Deflection Curves of SCCH-6 Job Mix at age of 60 Days and Exposed to temperature rates of $150,300,450$, and $600{ }^{\circ} \mathrm{C}$.

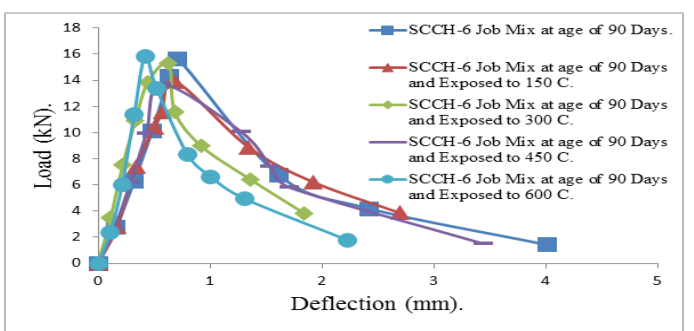

Fig. 10: Load-Deflection Curves of SCCH-6 Job Mix at age of 90 Days and Exposed to Temperature rates of $150,300,450$, and $600{ }^{\circ} \mathrm{C}$.

\section{Conclusions:}

According to test results, and its presentation in earlier, the in below conclusions can be mentioned:

1. It has noted an important increase in compressive strength of about $11.22 \%$ between 150 and $300{ }^{\circ} \mathrm{C}$ for RSCC job mix specimens at an age of 60 days, and $6.22 \%$ for HSCC job mix specimens for the same age, while at an age of 90 Days RSCC job mix specimens showed an increase of about $3.2 \%$ compared to $3.53 \%$ for HSCC job mix specimens, For HSCC job mix specimens, It has noted that for RSCC job mix specimens, the compressive strength for temperature rate of $450{ }^{\circ} \mathrm{C}$ as in table 15 decreased to $31.01 \%$ and $41.25 \%$ at an ages of 60 and 90 Days respectively compared to their relatives in table 14 not exposed to high temperature, and $41.32 \%$ and $48.39 \%$ for temperature rate of $600{ }^{\circ} \mathrm{C}$ at an ages of 60 and 90 Days respectively.

2. it has noted that for HSCC job mix specimens, the compressive strength for temperature rates of $450{ }^{\circ} \mathrm{C}$ decreased to $37.69 \%$ and $40.49 \%$ at an ages of 60 and 90 Days respectively compared to their relatives not exposed to high temperature, and $47.55 \%$ and $48.26 \%$ for temperature rate of $600{ }^{\circ} \mathrm{C}$ at an ages of 60 and 90 Days respectively, and this is due mainly to alteration of the porous network (Departure of bond water and decomposition of hydrates and to the microcracking).

3. It has noted that the flexural strength increased with age, and when the sample is subjected to increase in temperature exposure the behavior goes to be varied, so it is upon exposure to $300{ }^{\circ} \mathrm{C}$ there is a considerable increase in ultimate load and then decreased upon temperature exposures of $450 \& 600^{\circ} \mathrm{C}$.

4. The Flexural behavior of RSCC sample at age of 90 days is similar to that of 60 days but with small rates of deflection and this is due to continuous hydration which results robust microstructure can sustain loads.

\section{References:}

ASTM ${ }_{\text {C1018-97, "Standard Test Methods for }}$ Flexural Toughness and First-Crack Strength of Fiber-Reinforced Concrete (Using Beam with Third Point Loading)", Annual Book of ASTM Standards, Vol. 04.02, 2004; pp. 544-551.

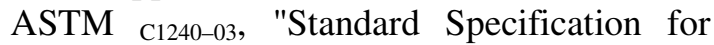
Use of Silica Fume as a Mineral Admixture in Hydraulic-Cement Concrete, Mortar, and Grout", Annual Book of ASTM Standards, Vol. 04.02, 2004; pp. 1-6.

BS 1881, Part 116, 1989, "Method for Determination of Compressive Strength of Concrete Cubes", British Standards Institution, 1881; PP. 3.

Eurocode 4-Calcul des structuresmixtesacier-béton. Partie 12: Règlesgénérales, calcul du comportement au feu, NF EN 1994-12. AFNOR, octobre 2005.

Khoury, G.A., Compressive strength of concrete at high temperature: a reassessment, Magazine of Concrete Research 44 (1992). 291-309. 
Okamura, H. and K. Ozawa, "Mix Design for Self-Compacting Concrete", Concrete Library of JSCE, 25(1995), pp. 107120.

Okamura, H. and M. Ouchi, "Self-Compacting Concrete", Journal of Advanced Concrete Technology, 1(1) (2003), pp. 5-15.

Iraqi Specifications \# 30 of year (1984). "Determination Sizes \& Shape of Aggregate Particles".

Iraqi Specifications \# 31 of year (1984) "Determination Density, Relative Density, Absorption, and Voids in Aggregate".

Iraqi Specifications \# 45 of year (1984) "Natural Aggregate used in Concrete and Construction".

Iraqi Specifications \# 5 of year (1984). "Portland Cement".

Khayat, K.H., Assaad, J. and Daczko, J. "Comparison of Field-Oriented Test Methods to Assess Dynamic Stability of Self-Consolidated Concrete", ACI Materials Journal, 101(2) (2004), pp. 168-176.

Kanema, M. Influence des paramètres de formulation etmicrostructurauxsur le comportement à haute température des bétons, Thèse de doctorat, Université de Cergy-Pontoise, (2007).

Su, N., Hsu, K.C. and Chai, H.W., "A Simple Mix Design Method for SelfCompacting Concrete", Cement and
Concrete Research, 31(2001), pp. 1799-1807.

Reference Guide Directory \# 198 of year (1990) "Physical Tests of Portland Cement", Iraqi Central Directory of Quality Control.

Reference Guide Directory \# 472 of year (1993). Iraqi Central Directory of Quality Control.

Reference Guide Directory \# 500 of year (1994). "Determination of Harmful Materials in Aggregate", Iraqi Central Directory of Quality Control.

Rilem Technical Committees 129-MHT, Test methods for mechanical properties of concrete at high temperatures, part 1 : introduction, part 2: stress-strain relation, part 3: compressive strength for service and accident conditions, Materials and Structures 28 (181) (1995). 410-414.

Taylor, W. H., "Concrete Technology and Practice", MC Graw Hill Book Company, $4^{\text {th }}$ Edition, (1977).

Zhu, W., Gibbs, C.J. and Bartos, P.J.M. "Uniformity of In Situ Properties of Self Compacting Concrete in Fullscale Structural Elements", Cement \& Concrete Composites, 23 (2001). pp. 57-64.

Xu, Y., Wong, Y.L., Poon, C.S., Anson, M., Impact of high temperature on PFA concrete, Cement and Concrete Research 31 (2001). 1065-1073.

\section{الملخص العزبى}

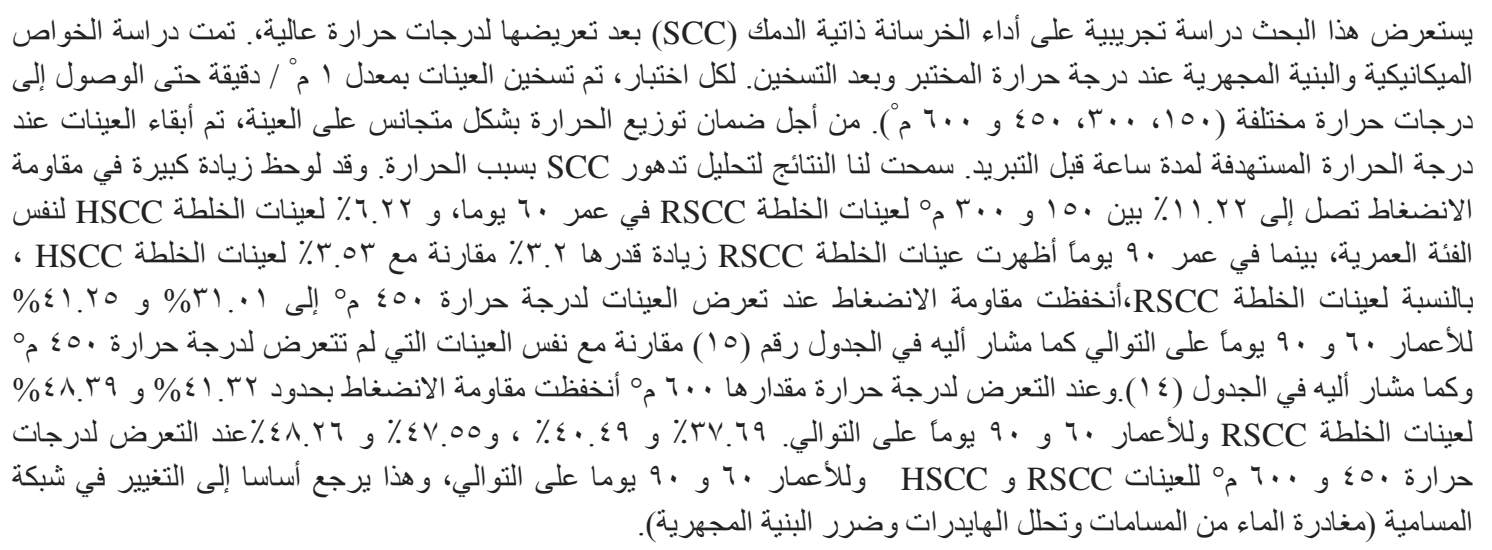

